\title{
OFICINA DE ESTUDIOS ECONÓMICOS
}

(Office of Economic Analysis)

DOCUMENTO DE TRABAJO № 31

(Working Paper № 31)

Assessing risks and regulating safety standards in the oil and gas industry: the Peruvian experience

Arturo Vásquez Cordano

Julio Salvador Jácome

Raúl García Carpio

Víctor Fernández Guzmán

Lima, February 2013

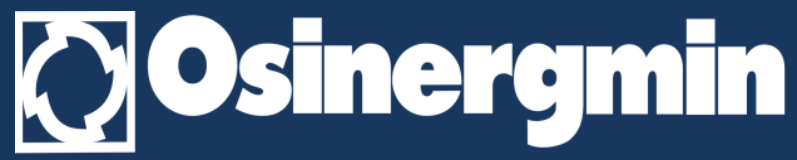




\section{Organismo Supervisor de la Inversión en Energía y Minería del Perú (Supervisory Agency of Investment of Energy and Mining of Peru) \\ Oficina de Estudios Económicos (Office of Economic Analysis)}

\section{Assessing risks and regulating safety standards in the oil and gas industry: the Peruvian experience.}

\section{Working Paper $\mathrm{N}^{\circ} 31$, Office of Economic Analysis}

The working papers series of the Office of Economic Analysis looks for contributing to the discussion of different aspects of the economic issues arising in the energy and mining sectors from an academic point of view. OSINERGMIN does not necessarily agree and cannot be held responsible for the opinions manifested in the paper. The ideas shown in the working papers belong to their authors and do not necessarily imply OSINERGMIN's institutional position. The information presented in this paper comes from reliable sources, but OSINERGMIN does not guarantee its completeness and exactness. The opinions and estimations presented in this paper represent the assessment and judgment of the authors given the available information and are subject to modifications without previous notice.

Total or partial reproduction of this paper is allowed as long as the source and authors are properly cited.

Authors: Arturo Vásquez Cordano, Julio Salvador Jácome, Raúl García Carpio and Víctor Fernández Guzmán

Assistants: Tatiana Nario Lazo and Steven Cueva Herrera.

First draft: February 2013

Cite the paper as: Vásquez Cordano, Arturo; Salvador, Julio; García, Raúl y Víctor Fernández (2013). Assessing risks and regulating safety standards in the oil and gas industry: the Peruvian experience. Working Paper $\mathrm{N}^{\circ} 30$, Office of Economic Analysis - OSINERGMIN, Peru.

It is requested to indicate in a visible place the bibliographic reference of the paper.

For comments and suggestions, please contact:

OSINERGMIN

Bernardo Monteagudo 222, Magdalena del Mar

Lima, Perú

Tel. (511) 219-3400, anexo 1057

Fax (511) 219-3413

Corporate Website

http://www.osinergmin.gob.pe/

Website of the Office of Economic Analysis

http://www.osinergmin.gob.pe/newweb/pages/Estudios Economicos/77.htm?6092

Emails: avasquez@osinergmin.qob.pe; rqarcia@osinergmin.qob.pe

ISSN $2307-4272$ (Online) 


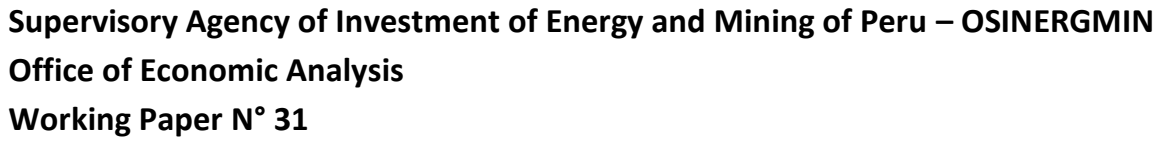

\title{
Assessing risks and regulating safety standards in the oil and gas industry: the Peruvian experience $^{1}$
}

\begin{abstract}
Environmental regulation has usually focused on controlling continuous sources of pollution such as $\mathrm{CO}_{2}$ emissions through carbon taxes. However, the 2010 oil spill in the Gulf of Mexico has shown that accidents associated to safety failures can also generate bursts of pollution with serious environmental consequences. Regulating safety conditions to prevent accidents in the oil and gas industry is challenging because public regulators cannot perfectly observe whether firms comply with safety laws. Likewise, it involves a complex political process in which different agents such as the government and oil companies interact and compete. This paper studies this problem in the case of Peru, providing a framework to analyze the enforcement of regulations designed to control safety standards in the oil and gas industry.

Regulating oil accidents demands a holistic approach, for the paper discusses different contributions from economics and game theory to understand the safety regulatory framework of Peru representing the interactions among the government, oil companies, and public regulators. It characterizes the optimal public enforcement strategy to prevent safety law violations causing accidents. Policy instruments such as self-reporting, monitoring and economic incentives are also analyzed considering the Peruvian experience.
\end{abstract}

It is possible to represent using a simple decision framework the complex institutional system governing safety regulations in Peru. Economic motives in an uncertain business environment drive law infringing behavior that leads to safety violations, so the government finds optimal to apply a

\footnotetext{
${ }^{1}$ This paper has been accepted to be presented at the SPE Latin American and Caribbean Conference on Health, Safety, Social Responsibility and Environment, Lima, Peru in June 2013. This is a pre-peer review version of the paper.
} 
law enforcement strategy that attacks these incentives. Oil and gas companies may find beneficial to comply with safety standards to minimize private losses associated to large accidents involving oil spills, gas pipelines leakages, etc.

Understanding how to properly regulate the occurrence of oil and gas accidents is fundamental for the legitimacy of the oil industry and governments' stability in a context where citizens demand improvements in safety standards and environmental quality. The analysis provided here can help oil firms and regulators in different jurisdictions assess the risks involved in oil and gas operations and the optimal ways to diminish them by considering appropriate regulations that balance the interests of companies and the governments' objective of protecting the environment and human health.

JEL Classification: D81, K23, L95. 


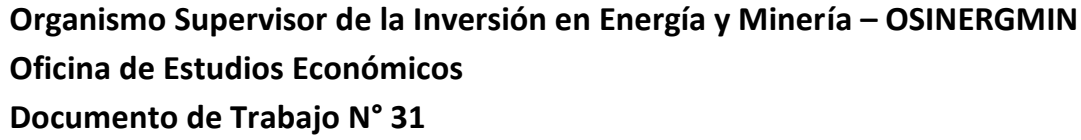

\section{Evaluando los riesgos y regulando los estándares de seguridad en la industria del petróleo y}

\section{gas: La experiencia peruana}

\section{Resumen}

La regulación ambiental usualmente se ha focalizado en controlar las fuentes de contaminación continua tales como las emisiones de $\mathrm{CO}_{2}$ a través de impuestos al carbono. Sin embargo, el derrame de petróleo en el Golfo de México en el año 2010 ha mostrado que los accidentes asociados a las fallas en seguridad pueden también generar brotes de contaminación con serias consecuencias ambientales. Regular las condiciones de seguridad para prevenir accidentes en la industria del gas y el petróleo es desafiante puesto que los reguladores públicos no pueden observar perfectamente si las empresas cumplen o no con las normas de seguridad. Asimismo, la regulación de la seguridad requiere un complejo proceso político en el cual compiten diferentes agentes económicos tales como el gobierno y las compañías petroleras. Este artículo estudia este problema para el caso del Perú, brindando un marco de análisis de la ejecución pública de las regulaciones diseñadas para hacer cumplir los estándares de seguridad en la industria del petróleo y el gas.

Regular los accidentes petroleros demanda un enfoque holístico; por lo tanto, este documento discute las diferentes contribuciones de la economía y la teoría de los juegos para comprender el marco regulatorio de la seguridad en el Perú, representando las interacciones entre el gobierno, las empresas petroleras y los reguladores públicos. El documento caracteriza la estrategia óptima de ejecución pública de las leyes para prevenir violaciones a las normas de seguridad que pueden causar accidentes. Instrumentos de política tales como auto-reporte, monitoreo e incentivos económicos son también analizados en la experiencia peruana.

Es posible representar, utilizando un simple modelo de toma de decisiones, el complejo sistema institucional que gobierna la regulación de seguridad en el Perú. La racionalidad económica en un escenario de negocios incierto estimula el comportamiento infractor de las normas que conduce a 
la violación de los estándares de seguridad. El gobierno encuentra óptimo el aplicar una estrategia de ejecución pública de las leyes que ataca estos incentivos. Las empresas de petróleo y gas, en este entorno, pueden encontrar beneficioso cumplir con los estándares de seguridad para minimizar las pérdidas privadas asociadas a grandes accidentes que involucren derrames de petróleo, fugas de gas en ductos, etc.

Comprender como regular apropiadamente la ocurrencia de accidentes en la industria del petróleo y gas es fundamental para la legitimidad del sector y la estabilidad del gobierno en un contexto donde los ciudadanos demandan mejoras en los estándares de seguridad y la calidad ambiental. El análisis provisto en este documento puede ayudar a las empresas petroleras y los reguladores en diferentes jurisdicciones a evaluar los riesgos inherentes a las operaciones de petróleo y gas y las maneras óptimas de disminuirlos considerando regulaciones apropiadas que den balance a los intereses corporativos de las empresas y el objetivo del gobierno de proteger el medio ambiente $y$ la salud humana.

Clasificación JEL: D81, K23, L95. 


\section{Table of Contents}

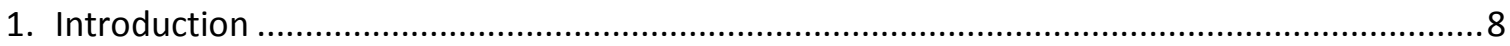

2. Identifying Safety Risks in Oil and Gas Activities: The Peruvian Case ......................................10

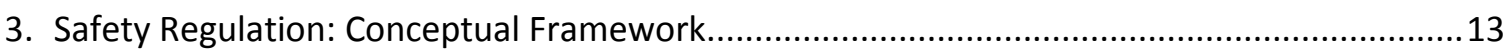

3.1. Setting the Socially Optimal Level of Safety Effort: A Theoretical Perspective .....................13

3.2. Informational Asymmetries regarding Safety Effort: The Principal-Agent Problem..............14

4. Safety Regulation in Practice: Monitoring the Oil and Gas Industry in Peru ............................20

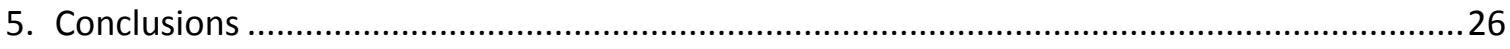

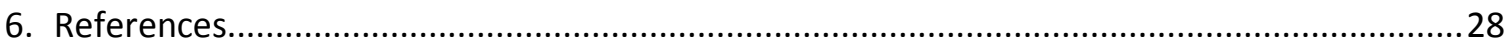

Appendix $\mathrm{N}^{\circ}$ 1: System of Self-Reporting through Affidavits....................................................... 


\section{Introduction}

The production technology used in the oil and gas industry is characterized by being inherently risky. Its application to extractive activities involves hazardous operations such as drilling, casing, cementing and completion of oil wells, pumping oil and gas through pipelines at high pressures, management of production water, and waste storage. These risky operations, if not managed safely, could generate accidents producing large adverse environmental impacts (accidental pollution ${ }^{2}$ ) and health threats to human beings if not handled according to safety standards established by law. Common accidents that may occur due to safety failures are oil spills, gas leakages and explosions of faulty equipment (e.g., oil rig and platforms).

A recent example of a safety failure in the oil and gas industry that produced massive environmental damages is the blowout of the Deep-water Horizon oil rig in the Gulf of Mexico in 2010. According to investigations made by several authors (e.g., Cavnar 2010, Vásquez 2012) and the White House (White House 2011), a small breach of safety standards in the completion of the Macondo well generated the death of thirteen workers and one of the biggest oil spills in human history. Over 4 million barrels of oil were spilled in that event, negatively affecting private property, recreational and fishing activities, wildlife, the ecosystems in the Gulf, the stability of local economies, among other adverse consequences.

This case constitutes an example of a safety infringement with a low probability of generating accidents that can produce a catastrophic event. These risks are often not well measured and can even affect the industry as a whole and its regulatory system (Viscusi 2006). It also illustrates why oil and gas companies' effort to comply with safety standard (henceforth, we denominate it safety effort) needs to be monitored and regulated. Since safety risks associated to oil and gas production may generate social harm such as negative environmental externalities and negative impacts on people's health (including the death of oil workers or citizens near faulty oil infrastructure), the State in several jurisdictions enforces safety standards in order to regulate the level of risk. This can be achieved by using traditional command and control mechanisms (Baumol and Oates 1987), ${ }^{3}$ by demanding that oil and gas companies have

\footnotetext{
${ }^{2}$ According to Vásquez "accidental pollution is any discrete discharge of pollutants to the environment that occurs sporadically in discrete amounts as a consequence of an accident [...] its nature is inherently random." (2012: 13)

${ }^{3}$ According to Baumol and Oates (1987) and Vásquez (2012), it is not possible to use traditional economic instruments such as subsidies and taxes to enforce safety standards to prevent accidental pollution because the occurrence of accidents is uncertain, making impossible to determine an exact base over which to apply either taxes or subsidies.
} 
insurance policies to cover operational risks and compensate damages or by a combination of both. Unfortunately, it is technically impossible to eliminate the risks of accidents in the oil and gas sector given the hazardous nature of the activities involved in the production stage, ${ }^{4}$ so what the State can achieve by regulating safety effort is to moderate to a tolerable level the amount of risk generated by oil and gas activities.

The objective of this paper is to analyze the problem of regulating risks and enforcing safety standards in the oil and gas sector taking as a case study the experience of Peru. We focus on the role of governmental regulation as a means to achieve companies' compliance with safety standards in the upstream subsector. We start by explaining the most important risks that may generate accidents in the upstream segment of oil and gas industry. Then, we analyze the conceptual economic framework that supports the regulation of safety standards in the oil and gas business by reviewing the existing economic literature on safety regulation. Regulating oil accidents demands a holistic approach, for the paper discusses different contributions from economics and game theory to understand the safety regulatory framework representing the interactions among the government, oil companies, and public regulators. It characterizes the optimal enforcement strategy to prevent safety law violations causing accidents. The application of policy instruments such as self-reporting, monitoring and economic incentives is also analyzed.

We continue our analysis by studying how safety monitoring and regulation in the oil and gas industry are implemented in Peru, explaining the policy instruments developed to ensure the compliance of safety standards and the protection of citizens using a preventive approach. Our focus in this paper will be on upstream activities. Finally, we conclude the paper proposing some policy recommendations to improve safety regulations in the oil and gas industry considering the Peruvian experience.

Instead, these instruments can be used to regulate continuous sources of pollution such as $\mathrm{CO} 2$ or SO2 emissions since the informational burden to apply them is not large given the progress in technologies to measure continuous emissions of pollutants (Stavins 1998).

\footnotetext{
${ }^{4}$ Vásquez (2012) and Cohen (1987) provide an explanation of the impossibility to eliminate safety risk in the oil sector and present a mathematical explanation of why the properties of the risky technology used in the oil and gas sector cannot eliminate the risk of accidents by increasing the degree of safety effort.
} 


\section{Identifying Safety Risks in Oil and Gas Activities: The Peruvian Case}

In Peru oil and gas activities have some characteristics that make them more risky. In the upstream subsector, these activities comprise mainly seismic surveys and other exploratory activities, drilling, extraction and transportation operations. In Peru, the majority of oil and gas blocks with important reserves are located in remote areas of the Amazon rainforest, which comprises a region with fragile ecosystems and several local communities. In this region well drilling and completion is a dangerous activity that may have adverse environmental impacts if not managed safely. For instance, this activity involves the manipulation of hazardous elements such as drilling muds, radioactive and completion materials; if they are released into the rainforest, they may generate the degradation of soil, the pollution of water sources, the death of animals and adverse effects to human health. Drilling rigs for exploratory wells are mainly helitransportable; each one requires a field covering an area of approximately 2 hectares to install drilling infrastructure, a heliport, workers' camps and other complementary facilities. The installation of drilling rigs in the jungle requires safety measures to prevent potential accidents affecting the life of workers and avoid excessive deforestation in the surrounding areas of the field.

Once oil and gas are found and its commerciality is determined, they are produced using electro-mechanical and submersible pumps. Blowout preventers and other control mechanisms allow regulating excess pressure in the wellhead to prevent the occurrence of catastrophic explosions and the release of hydrocarbons to the environment. Extracted fluids are transported through pipelines inside the field to pre-processing facilities that separate oil and gas from water and other toxic components. Production water and other toxic materials should be treated and disposed safely to avoid its direct discharge to the atmosphere and rivers. Excess natural gas that cannot be sold should be flared, used for internal combustion in electric generators inside the field or re-injected into the reservoir. Once oil and gas are pre-processed, they are transported through pipelines to export terminals or refineries. At this stage, pipeline administrators should manage safely the pressure at which oil and gas fluids are transported to prevent explosions during pumping operations. Likewise, administrators should monitor the integrity of the pipeline network to avoid oil and gas leakages or spills. 
Failures in the safety management of oil and gas activities in the upstream sector can generate accidents such as oil spills or gas leakages that may release pollutants like production water and toxic materials with negative environmental consequences to the rainforest and local communities near oil and gas facilities. This problem has been a hot topic in Peru since the beginning of oil and gas operations in the Peruvian rainforest in 1971. Before the 1990's there were not strict environmental laws regulating oil and gas activities, and safety standards were not so demanding for oil companies. The release of toxic pollutants and production water was in practice not well monitored in the rainforest, which caused the accumulation of environmental liabilities for decades. Former oil companies that operated in the area, left exploratory and production wells without specific abandonment plans and left non-biodegradable waste contaminants above ground without being disposed in appropriate landfills. These pollutants are not easy to locate because they were covered by vegetation regenerated naturally. The release of production water, the discharge of toxic waste, the occurrence of oil spills and the venting of natural gas generated in the past several environmental impacts affecting the ecosystems and local communities (Villar 2009). These impacts are still in the memory of the affected people and have been disseminated by the popular press, which has created an important opposition against more oil and gas activities in the Peruvian rainforest.

Table $\mathrm{N}^{\circ} 1$ presents a summary of the risks generated by oil and gas activities in the Peruvian rainforest which are organized by the type of hazard and the probability of the events. In some cases the same event may have different impacts on human life and the environment. There are also regular or frequent events of moderate impact and very infrequent but catastrophic events which are hard to control. As the reader can see, oil and gas activities in the upstream sector generate multiple hazards for the environment and the integrity of local communities with different levels of severity and probabilities of occurrence.

A safety failure may produce catastrophic accidents impacting multiple parties and degrading a fragile environment, which may generate large liabilities to oil and gas companies and social instability. In order to prevent the occurrence of accidents, safety regulation is crucial. If oil and gas companies comply with safety standards, they can legitimate their activities in front of local communities and the civil society, guaranteeing social order and the stability of their operations. However, in certain cases, some companies may find economic to shirk their duties so as to avoid safety costs and obtain illicit benefits. This tendency can be corrected by a proper enforcement of safety regulations conducted by the State and the appropriate setting of safety standards. In the next section, we explain, from a conceptual standpoint, how the State can 
achieve safety compliance by setting optimal safety standards and delegating regulatory power to specialized regulatory agencies.

Table $\mathbf{N}^{\circ} 1$

Risk Ranking for Upstream Oil and Gas Activities in the Peruvian Rainforest

\begin{tabular}{|c|c|c|c|c|}
\hline \multirow{2}{*}{$\begin{array}{c}\text { Probability } \\
\text { (R) }\end{array}$} & \multicolumn{4}{|c|}{ Hazard (IN) } \\
\hline & Minor & Moderate & Major & Catastrophic \\
\hline \multicolumn{5}{|c|}{ Oil and Gas: Exploration and Extraction } \\
\hline Rare & & & $\begin{array}{c}\text { Failure of safety } \\
\text { systems (e.g., blow } \\
\text { out preventers) }\end{array}$ & $\begin{array}{c}\text { Explosion of wells } \\
\text { due to } \\
\text { completion } \\
\text { failure }\end{array}$ \\
\hline \multirow[b]{2}{*}{ Occasional } & \multicolumn{3}{|c|}{ Impact on the quality of soil by an oil spill. } & \\
\hline & $\begin{array}{l}\text { Displacement of } \\
\text { wildlife by } \\
\text { industrial-scale } \\
\text { human presence } \\
\text { and disappearance } \\
\text { of vegetation }\end{array}$ & $\begin{array}{l}\text { Impact on human } \\
\text { health by polluting } \\
\text { air quality due to } \\
\text { releases of gases } \\
\left(\mathrm{NO}_{x}, \mathrm{CO}_{2}, \mathrm{CO}\right)\end{array}$ & & \\
\hline \multirow[b]{2}{*}{ Periodic } & \multicolumn{3}{|c|}{ Impact on surface water by oil spills and household waste camps } & \\
\hline & $\begin{array}{l}\text { Impact on the } \\
\text { quality of soil by } \\
\text { vegetation loss }\end{array}$ & & & \\
\hline Frequent & & $\begin{array}{l}\text { Greenhouse gas } \\
\text { emissions }\end{array}$ & & \\
\hline \multicolumn{5}{|c|}{ Transportation of Hydrocarbons } \\
\hline \multicolumn{5}{|l|}{ Rare } \\
\hline Occasional & & $\begin{array}{c}\text { Impact on } \\
\text { groundwater by } \\
\text { drainage of oil or } \\
\text { natural gas liquids } \\
\text { from a broken } \\
\text { pipeline. }\end{array}$ & & \\
\hline \multirow[b]{2}{*}{ Periodic } & \multicolumn{3}{|c|}{ Impact on the quality of soil by oil spills } & \\
\hline & & & $\begin{array}{c}\text { Impact to } \\
\text { groundwater from } \\
\text { spills or leaks of } \\
\text { hydrocarbons }\end{array}$ & \\
\hline
\end{tabular}

Source: Own elaboration 


\section{Safety Regulation: Conceptual Framework}

\subsection{Setting the Socially Optimal Level of Safety Effort: A Theoretical Perspective ${ }^{5}$}

As mentioned in the previous section, the setting of safety standards in the oil and gas industry and its enforcement is relevant because the violations of them may generate an increasing risk of accidents with adverse consequences to the environment and human health. However, investment in safety measures to comply with the standards is a costly activity for companies, so it is necessary to make an analysis of the optimal level of safety considering the costs and benefits of safety policies. From a conceptual perspective, this cost-benefit analysis can be modeled considering that the expected social cost of providing safety (ESCS) is equal to the difference between the expected value of social damage, $\operatorname{ESD}(u)$, and the expected cost of providing safety, $\operatorname{TSC}(u)$, where $u$ is the level of safety effort exerted by the oil and gas industry:

$$
\operatorname{ESCS}=\operatorname{ESD}(u)-\operatorname{TSC}(u) .
$$

We assume that $\operatorname{ESD}(u)$ and $\operatorname{TSC}(u)$ are convex functions; in the case of $\operatorname{TSC}(u)$, it is an increasing function of $u$ which means that the cost of improving safety conditions is higher as the company exerts a higher level of safety effort. $\operatorname{ESD}(u)$ is a decreasing function of $u$, which means that the expected social damage diminishes as the companies' safety effort improves. ESCS, ESD $(u)$ and $\operatorname{TSC}(u)$ are depicted in Figure 1.

Figure $\mathbf{N}^{\circ} 1$

Optimal Determination of Safety Standards

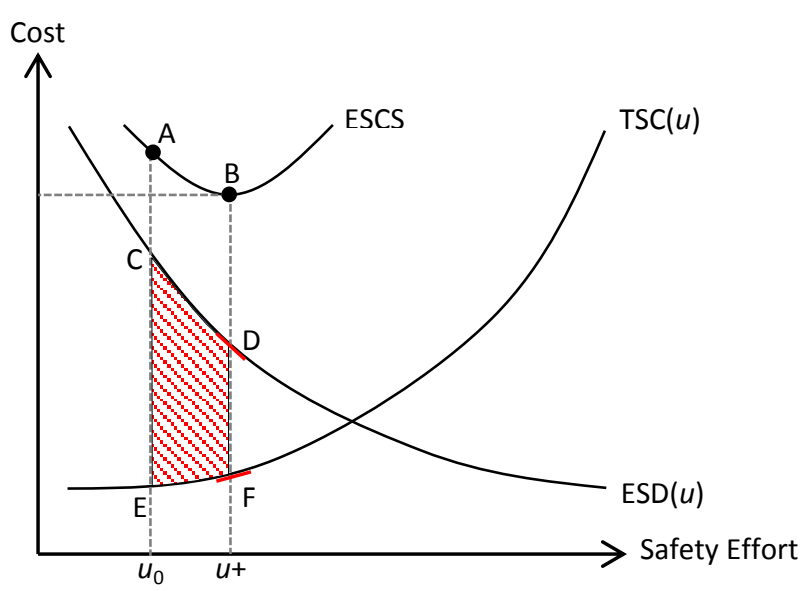

Source: Own elaboration

\footnotetext{
${ }^{5}$ This section is based on Viscusi et al (2000), Chapter 22.
} 
The objective of the State is to set a safety standard, $u+$, that minimizes the expected social cost of providing safety. Figure $\mathrm{N}^{\circ} 1$ illustrates that this objective is achieved when the expected marginal cost of providing safety (point D, where the derivative of TSC represented by the tangent line is the marginal cost) is equal, in absolute value, to the marginal reduction in the expected social damage (point F). This equilibrium condition is achieved at $u+$, representing the optimal safety standard that the State should apply in the oil and gas industry.

In case a company exerts a safety effort, $u_{0}$, which is less than $u+$, we observe in Figure $N^{\circ} 1$ that the expected marginal cost of providing safety is less than the expected marginal social damage. In this scenario the risk of an accident increases beyond its optimal level (achieved when $u+$ is choosen); in other words, there is too much risk of an accident that is born by society. Mathematically, we can value this excess risk to society by measuring the social loss, $S L$, due to a safety effort below its optimal standard, which is shown as the shaded area defined by the region CDEF in Figure $\mathrm{N}^{\circ} 1$. This social loss shows up because a safety effort below the standard increases the expected social damage that society can face due to the higher risk of an accident. The mathematical expression of this social loss, assuming that it is possible to perfectly identify functions $E S D(u)$ and $T S C(u)$ is

$$
S L=\int_{u_{0}}^{u^{+}}[\operatorname{ESD}(u)-T S C(u)] d u
$$

To restore the equilibrium condition and eliminate the social loss of excess risk, the State needs to induce the company to exert a level of effort which is consistent to $u+$. This is a difficult task since the State does not possess direct information regarding the companies's safety behavior. Actually, there is an informational asymmetry regarding safety effort between the State, which cannot verify a priori safety effort, and the companies, which exactly know how they perform regarding safety compliance. In the next section we explain how the State can achieve its objective of guaranteeing the compliance of safety standards by implementing safety regulations in an environment of asymmetric information.

\subsection{Informational Asymmetries regarding Safety Effort: The Principal-Agent Problem}

Safety regulation of oil and gas activities is understood in the economic literature as a problem of asymmetric information between the State and a regulated company (Vásquez 2012, Cohen 
1987). The informational asymmetry originates due to the fact that an oil and gas company has better information regarding its risky activities and its safety effort to prevent accidents than the State, which cannot perfectly observe the company's behavior with respect to safety compliance. This explains why a company can have, in general, incentives to reduce its safety effort.

As mentioned before, the problem is that a reduction of safety effort below a certain critical level can increase the risk of accident to a socially intolerable degree, generating negative externalities (such as environmental damage or adverse health impacts) to society. This problem, also known in the economic literature as moral hazard, justifies the State's intervention by delegating its regulatory power to a specialized agency. This agency is able to obtain better information on the company's safety performance by implementing monitoring and supervisory strategies, closing to some extent the informational gap between the public authority and the company. In this way, the regulatory agency becomes an "information intermediary" between the State and the oil and gas company which administers information regarding safety effort by monitoring the company's activities and enforcing safety standards using economic incentives such as monetary and nonmonetary penalties (Shavell 2004, Polinsky and Shavell 2007).

According to Vásquez (2012), the problem of moral hazard observed when dealing with the compliance of safety effort in the oil and gas industry can be formalized by means of a principalagent model. This model explains the hierarchical relationship between an oil and gas company (the agent subject to regulation) and a regulatory agency (the principal which has the State's command to enforce safety regulations). This relation is presented in Figure $\mathrm{N}^{\circ} 2$.

Figure $\mathbf{N}^{\circ} 2$

Principal-Agent Relationship

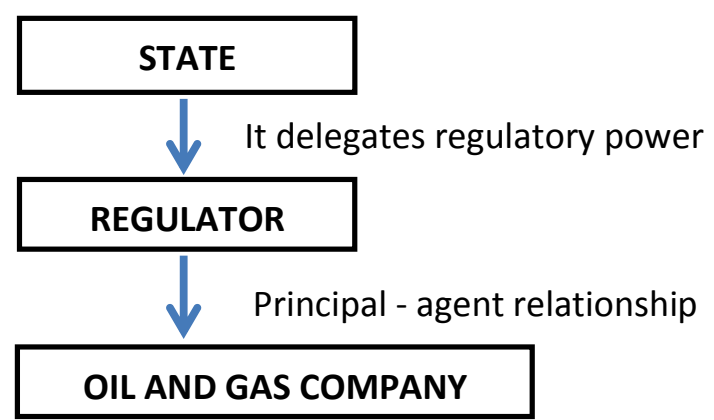

Source: Own elaboration 
The company performs a risky activity (e.g., the completion of an oil well, the transportation of natural gas at high pressure through a pipeline) which is not directly observed by the agency, but it affects the probability of occurrence of accidents. A higher level of the company's safety effort contributes to the reduction in the probability of accidents. In this context, the regulatory agency has to design incentive mechanisms to induce the company that commits the necessary safety effort so as to comply with safety standards. Command and control instruments such as monitoring, monetary fines and non-monetary penalties have been identified in the law and economics literature as incentive mechanisms to regulate firms' safety behavior in the case where there are bilateral relations between the regulatory agency and the company (Becker 1968, Cohen 1987, Baumol and Oates 1988, Polinsky and Shavell 2007).

Economic theory establishes that the optimal level of safety monitoring and the optimal values of penalties for safety infringements are determined by solving the problem of the regulator who looks for maximizing expected social welfare (the objective of a benevolent State) subject to budget constraints, information restrictions guaranteeing that the company participate in the regulatory scheme and that the company's incentives be compatible with the regulator's objective (Hölmstrom 1979), limited liability constraints that are established in corporate law (Shavell 1987) and other restrictions related to the political environment (Tirole 1986, Hiriart et al. 2010, Vásquez 2012).

A simplified version of the principal-agent model applied to safety regulation is illustrated in Figure $\mathrm{N}^{\circ} 3 .^{6}$ We observe the interaction between the regulatory agency and an oil and gas company which performs a risky activity by means of the extended form of a game with six stages. ${ }^{7}$ In the first stage (which starts at the first decision node), the regulator chooses the level of monitoring effort, $e$, that will commit to oversee the company's safety behavior. In the figure, we assume that the regulator can choose only two options: a high $\left(e_{H}\right)$ or a low $\left(e_{L}\right)$ level of monitoring effort. Executing monitoring activities imply that the regulator spend limited public funds (given that regulators are usually subject to public budget restrictions) to afford inspection and administrative activities (including the application of economic incentives to infringers such as fines) targeted to control the company's safety performance. This means that monitoring is

\footnotetext{
${ }^{6}$ Vásquez (2012), Chapter 4, presents a complete development of the principal-agent model presented here which is applied to understand the economic implications of safety regulation in the oil and mineral industries. It considers a more complex institutional environment with multiple regulatory agencies and the possibility of regulatory capture.

${ }^{7}$ For more details about the extended form of sequential games, see Laffont and Tirole (1993), Chapter 3.
} 
socially costly, and it is impossible to achieve perfect monitoring given the limited budgetary resources available to regulators and the problem of asymmetric information described above.

\section{Figure $\mathbf{N}^{\circ} \mathbf{3}$}

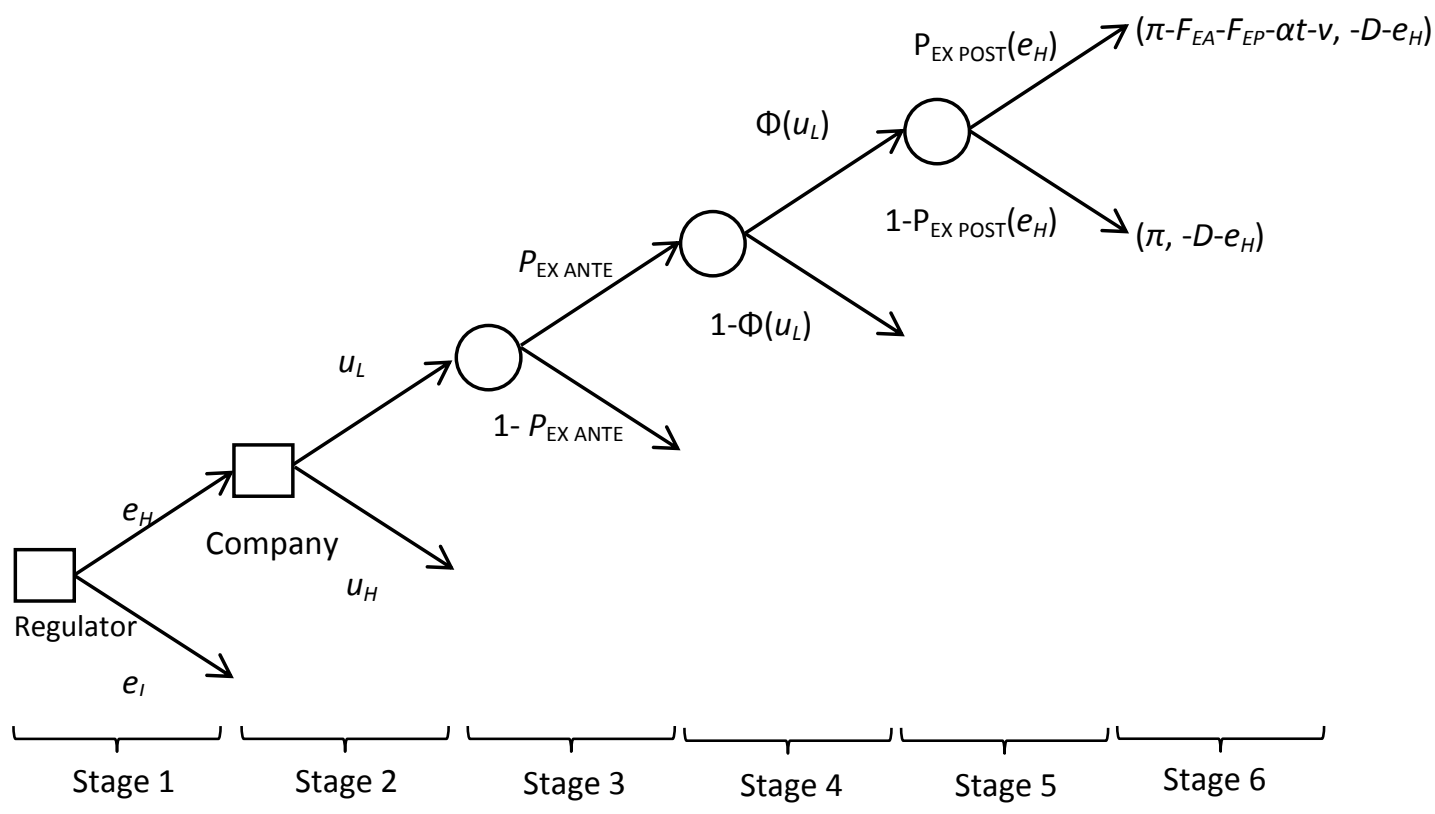

Source: Own elaboration

In the second stage of the game (which starts at the second decision node), we assume that the company can choose whether to exert a high $\left(u_{H}\right)$ or low $\left(u_{L}\right)$ level of safety effort given the regulator's decision regarding its monitoring effort in the first stage. In the third stage, the regulator carries out ex ante monitoring in order to evaluate the degree of the company's safety compliance before the occurrence of an accident. This type of monitoring has a preventive nature since it can incentivize the company to reduce ex ante the likelihood of accidents by investing in safety measures. In this way, the regulator can reduce the risk of accidents, preventing the occurrence of large social damages. The ex ante probability of detecting safety infringements is called $P_{\text {EX ANTE }}$ (shown in the first probability node). If the regulator chooses $e_{H}$, $P_{\text {EX ANTE }}$ will be high inducing the company to probably exert a high level of safety effort. Otherwise, the company will likely exert a low level of safety effort.

Then, the game considers a fourth stage (represented by the second probability node in Figure 3) where an accident can happen with probability $\Phi(u)$. Note that this probability depends on $u$, so it is likely that if the company exerts $u_{L}$, the occurrence of an accident will be more likely. This result reinforces the preventive nature of ex ante monitoring in the safety regulatory framework 
highlighted above: it is the one that can reduce the likelihood of accidents and, therefore, the occurrence of social damages. Figure 3 shows a branch of the extended form of the game in which the company has chosen $u_{L}$, so the probability of an accident with a high level of safety effort will be higher in that scenario than in the case where the company chooses $u_{H}$.

If an accident happens, the game follows to a fifth stage (third probability node in Figure $\mathrm{N}^{\circ} 3$ ) where the regulatory agency can oversee what happens with the conduct of the company during the accident and also can assess whether any social harm has been generated. The regulatory agency can detect any infringement and harm with probability $P_{E X}$ POST. This type of monitoring happens after the occurrence of the accident, so it is a reactive form of monitoring (the regulatory agency supervises the company only if an accident happens). It allows generating ex post incentives to the company to abide by the safety standards and internalize any social harm generated by its illicit behavior in the future. However, according to Kolstad, Ulen and Johnson (1990), using alone ex post monitoring cannot guarantee that the company has enough incentive to exert a high level of effort since it cannot induce, ex ante, a high level of safety effort due to the fact that the company's decision to choose $u_{H}$ is taken before the occurrence of an accident. Thus, it is necessary to use both ex ante and ex post monitoring to align the company's incentives towards safety compliance.

Finally, in the sixth stage we observe the payments of the players in the regulatory game. In Figure 3 we show the payments of the first branch of the tree. The company receives in that branch the expected profit of its strategy of choosing $u_{L}$. Since $u_{L}<u^{+}$, the company has violated the safety standard. In this scenario it obtains $\pi\left(u_{L}\right)$ as profit. Note that $\pi\left(u_{L}\right)>\pi\left(u_{H}\right)$ since exerting a higher level of safety effort is more costly to the company, requiring higher investments in safety measures to prevent accidents. Therefore, when the company chooses $u_{L}$ it obtains an illicit benefit since it is avoiding safety compliance cost. That illicit benefit is measured by $\pi\left(u_{L}\right)-\pi\left(u_{H}\right)$.

In order to induce the company to abide by the safety standard, $u+$, the regulator can apply economic incentives such as monetary fines and nonmonetary penalties. $F_{E A}$ is the expected fine the regulator can assess if ex ante monitoring reveals that $u_{L}<u^{+} . F_{E P}$ is the expected fine the regulator can apply if ex post monitoring reveals a safety infringement. $\alpha t$ is equal to the expected value of the opportunity cost the company faces if its facilities are shut down for $t$ periods as a nonmonetary sanction applied by the regulator in an scenario where the level of 
safety risk is too high. $v$ is the expected private loss the company faces if an accident happens. ${ }^{8}$ The total payoff the company may receive at the end of the game is equal to $\pi-F_{E A}-F_{E P}-\alpha t-v$, which is the net profit the company may receive after the application of the regulator's penalties and the internalization of the company's private loss for the accident, $v$. The regulator receives a negative payoff of $-D-e_{H}$, which is equal to the expected social harm or damage, $-D$, plus the expense committed to monitoring $\left(e_{H}\right.$ is shown in the Figure 3 since the illustrated branch considers that the regulator chose a high level of monitoring effort in the first stage of the game).

The model described above shows the inherent conflict of interest between the safety regulator and the oil and gas company. While the regulator, representing the State, wants to minimize the expected social cost of accidents (measured by the social damage and the expenses in monitoring efforts which has a public opportunity cost), the company wants to maximize its expected net profit. In order to align the objectives of the State and the company, the regulator needs to devise a regulatory mechanism that makes private and public incentives compatible (i.e., safety regulation should be carried out in such a way that both the State and the company achieve their objective in a consistent way) and allows the participation of the company in the oil and gas activity (i.e., the safety regulation should allow the company to recover the costs of its activities in order to make attractive its participation in the oil and gas business). ${ }^{9}$ In order to do that, the regulator must choose its monitoring effort, $e$, and its penalty instruments $\left(F_{E A}, F_{E P}\right.$ and $t$ ) so as to guarantee an appropriate level of ex ante and ex post detection of safety infringements and an adequate level of deterrence of violations that induce the company to choose a high level of safety effort, $u_{H}$. This in turn minimizes the risk of an accident and the occurrence of social harm (the objective of the State) while maximizing the company's expected profit at the same time.

The model also indicates that in is the absence of a public safety regulatory policy, the company's level of safety care would be low given the lack of economic incentives for compliance in this scenario, and the risk of an accident would be high, increasing the probability of observing significant social harm. The company will only exert enough safety effort to reduce

\footnotetext{
${ }^{8}$ For instance, the company may face positive replacement costs when an accident generates the destrucition of relevant machinery and equipment like oil rigs. Another example of a private resource loss is the value of oil or gas in an oil spill or gas leakage.

${ }^{9}$ In the principal-agent literature these constraints are known as incentive-compatibility and participation constraints.
} 
its expected private loss, $v$, after an accident, which may not be desirable from a social standpoint since the company's risky activity may also generate $D$. This implies that in the absence of regulation, "auto regulation" measures implemented by the company, such as the implementation of a private safety management system will be mainly focused on controlling risks to avoid private losses.

The economic theory presented until here allows understanding the need of having safety regulations to control the risk of accidents in the oil and gas industry, but it does not tell us how a regulatory agency can implement monitoring policies to deal with safety enforcement, especially in the ex ante stage where the regulations can actually prevent risky situations and the occurrence of accidents. In the next section, we show how this task is performed in the case of Peru, where innovative policies have been designed to prevent accidents in the Peruvian oil and natural gas industry.

\section{Safety Regulation in Practice: Monitoring the Oil and Gas Industry in Peru ${ }^{10}$}

The Peruvian State has delegated to the Supervisory Agency of Investment in Energy and Mining (OSINERGMIN) the role of monitoring and supervising of oil and gas companies as well as enforcing safety standards by means of the application of penalties as a deterrence measure for infringements of safety compliance. The Peruvian Hydrocarbons Law and its rules of procedures (Law No 26221) has divided the monitoring activities of the oil industry into four stages: a) the pre-operative stage where the State's approval is required to start oil and gas activities, b) the operational stage in which OSINERGMIN verifies that the activities are carried out under the same safety conditions that were established when the State's license of operation was granted, c) the abandonment plan which implies the closure of facilities and the reclamation of affected land, and d) special supervision (e.g., fuel quality inspections, metrology and the control of informal trade of fuels). This scheme has been the traditional way to perform safety monitoring in Peru since the 90's (Villar 2012).

However, the start of operations of the Camisea gas project in the Peruvian rainforest in 2004 allowed the production of large quantities of gas, fact that has dramatically transformed the energy panorama in Peru. In this new scenario, OSINERGMIN has had to adapt in the last years its monitoring and supervision processes in order to deal with the new safety challenges brought

\footnotetext{
${ }^{10}$ This section is based on Salvador and Fernández (2011).
} 
about by the development of the gas infrastructure in Peru. This adaptation process has been oriented to ensure that safety standards are complied in the development of large gas facilities (LNG export terminals, gas production fields, processing plants, etc.), transport infrastructure (gas pipelines) and gas distribution networks.

In this context, OSINERGMIN has developed a supervision model that seeks to reduce the risk of accidents through the intervention of different agents and the appropriate assignment of responsibilities in order to align incentives toward meeting the required safety standards for the oil and gas industry ex ante the occurrence of accidents. The model starts by carrying out an appropriate risk assessment, which classifies the different activities in the oil and gas industry according to their risk levels and identifies the best ways to reduce the likelihood of accidents. The stages of this process, which has been certified under the norm ISO 31000-2009, are shown in Figure $\mathrm{N}^{\circ} 4$.

Figure $\mathbf{N}^{\circ} 4$

Risk Management Process

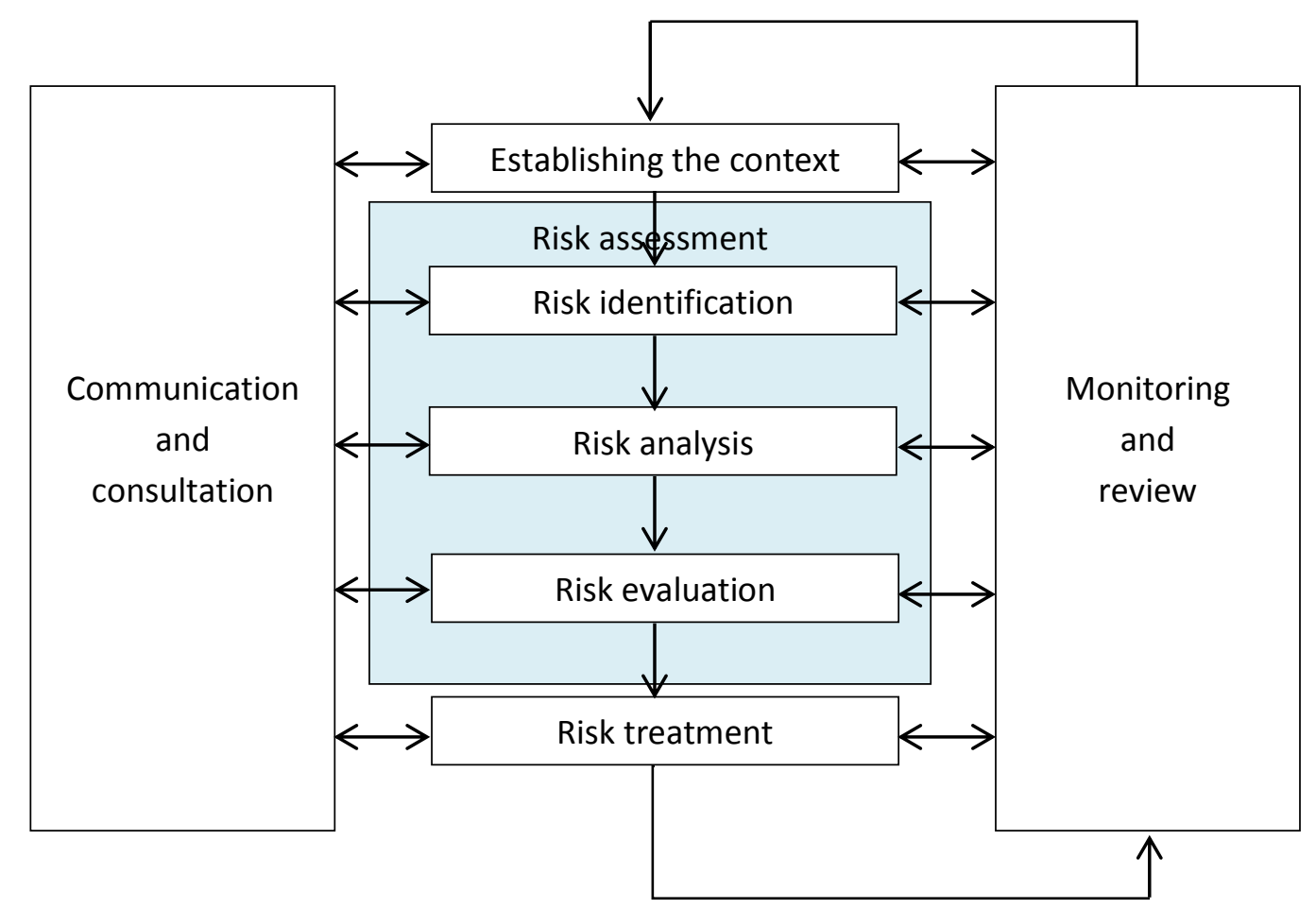

Source: Own elaboration

The risk assessment stage is a key to identify the measures to mitigate them and assign responsibilities among the participants in the industry. OSINERGMIN has classified the safety risks in two categories: internal and environmental risks, as shown in Figure $\mathrm{N}^{\circ} 5$. 
Figure $\mathbf{N}^{\circ} 5$

Identification and action at risk

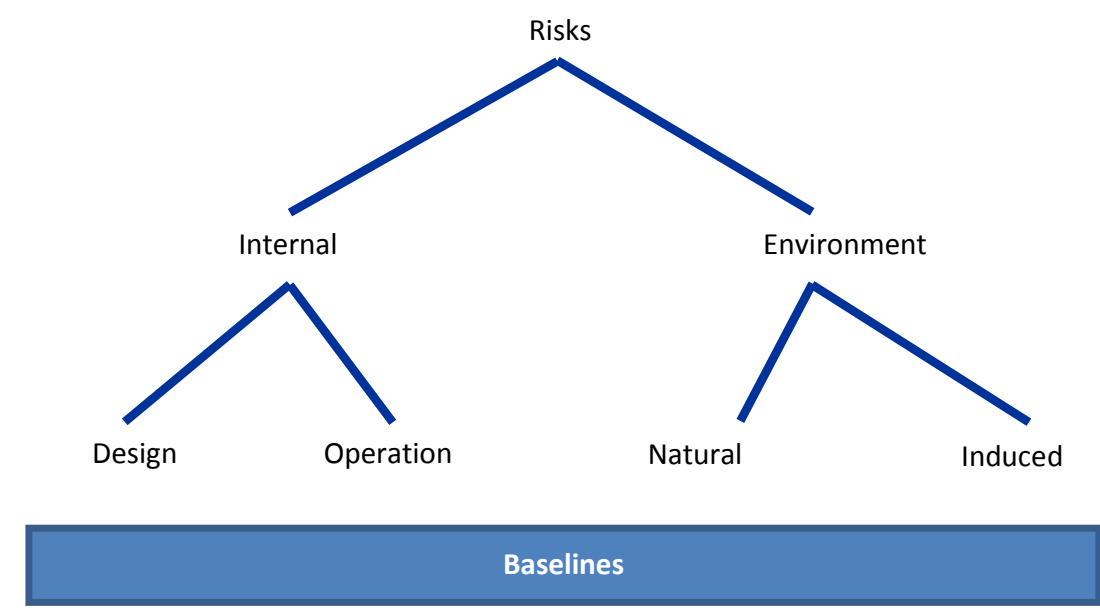

Source: Own elaboration

After the assessment of risks and the identification of the mitigation actions, the regulator proceeds to classify the activities if they exhibit critical, moderate or low risks to safety. The monitoring policy and supervision activities are designed based on this classification. The model considers that the activities with high risk should be monitored more often (given that those can generate larger social damages), while the activities with moderate or low risk should be monitored less frequently in order to minimize the costs associated to the regulator's monitoring effort (Mondello 2011) and manage efficiently the supervision of safety compliance. These monitoring costs are considered when the supervision plan of oil and gas facilities is executed and when the penalty system for safety infringements is established. Monetary penalties are designed considering the economic theory on public law enforcement taking into account the probability of detection, illicit profits or avoided costs related to safety infringements and measures of the social damage generated by the accidents. ${ }^{11}$

The model, which design is shown Figure $\mathrm{N}^{\circ} 6$, grants special attention to direct monitoring and control ex ante and ex post the occurrence of accidents. In this regard, the approach adopted in Peru for safety monitoring is consistent with what the specialized literature on safety regulation recommends as discussed in Section 3. This is complemented with the generation of technical regulations that are objective and transparent for the oil and gas companies.

\footnotetext{
${ }^{11}$ See Polinsky and Shavell (2000), Vásquez and Gallardo (2006), and Vásquez (2006).
} 


\section{Figure $\mathbf{N}^{\circ} 6$}

\section{Design of the Supervision System}

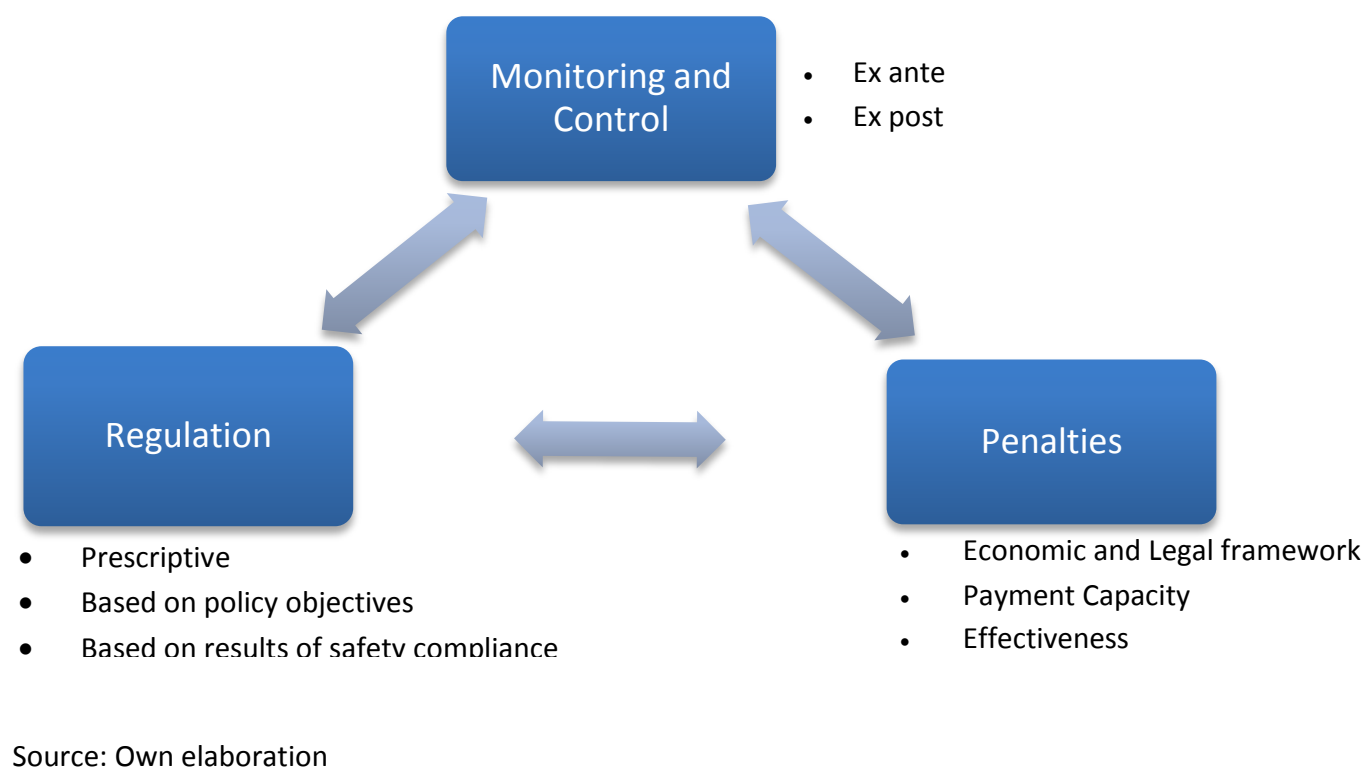

The safety monitoring model seeks to ensure the continuous monitoring of oil and gas activities. This objective is achieved at a first stage by oil and gas companies since the system provides incentives for them to autoregulate their safety effort through a self-report of safety compliance to the regulatory agency. The system reinforces the incentives to compliance in a second stage by allowing regular random inspections or special supervisions based on the evaluation of the risks that the companies report. This approach seeks that the regulator has an early assessment of risks in order to mitigate them as soon as possible. Figure $\mathrm{N}^{0} 7$ summarizes the organization of activities inside the model. Appendix1 describes the self-report scheme organized to autoregulate activities in the first stage of the model.

In the event that safety risks exceed certain thresholds, the regulator takes emergency actions like the suspension of activities. The regulator mandates mitigation measures and remedial controls to return the company involved in the risky event to a status of safety compliance in which the company can achieve its previous risk level (see Figure $N^{\circ} 8$ ). 
Figure $\mathrm{N}^{\circ} 7$

Safety Monitoring: Organization of Activities

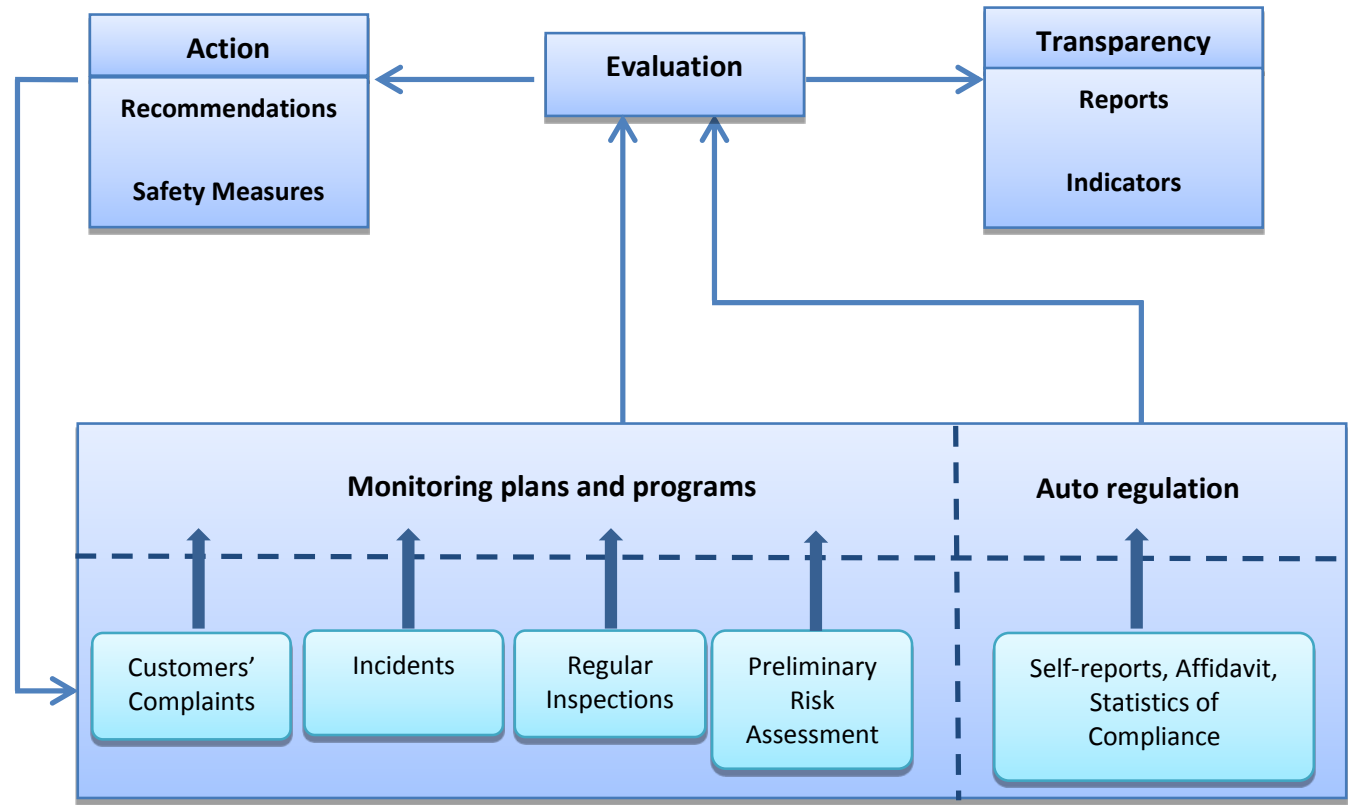

Source: Own elaboration

Figure $\mathbf{N}^{\circ} 8$

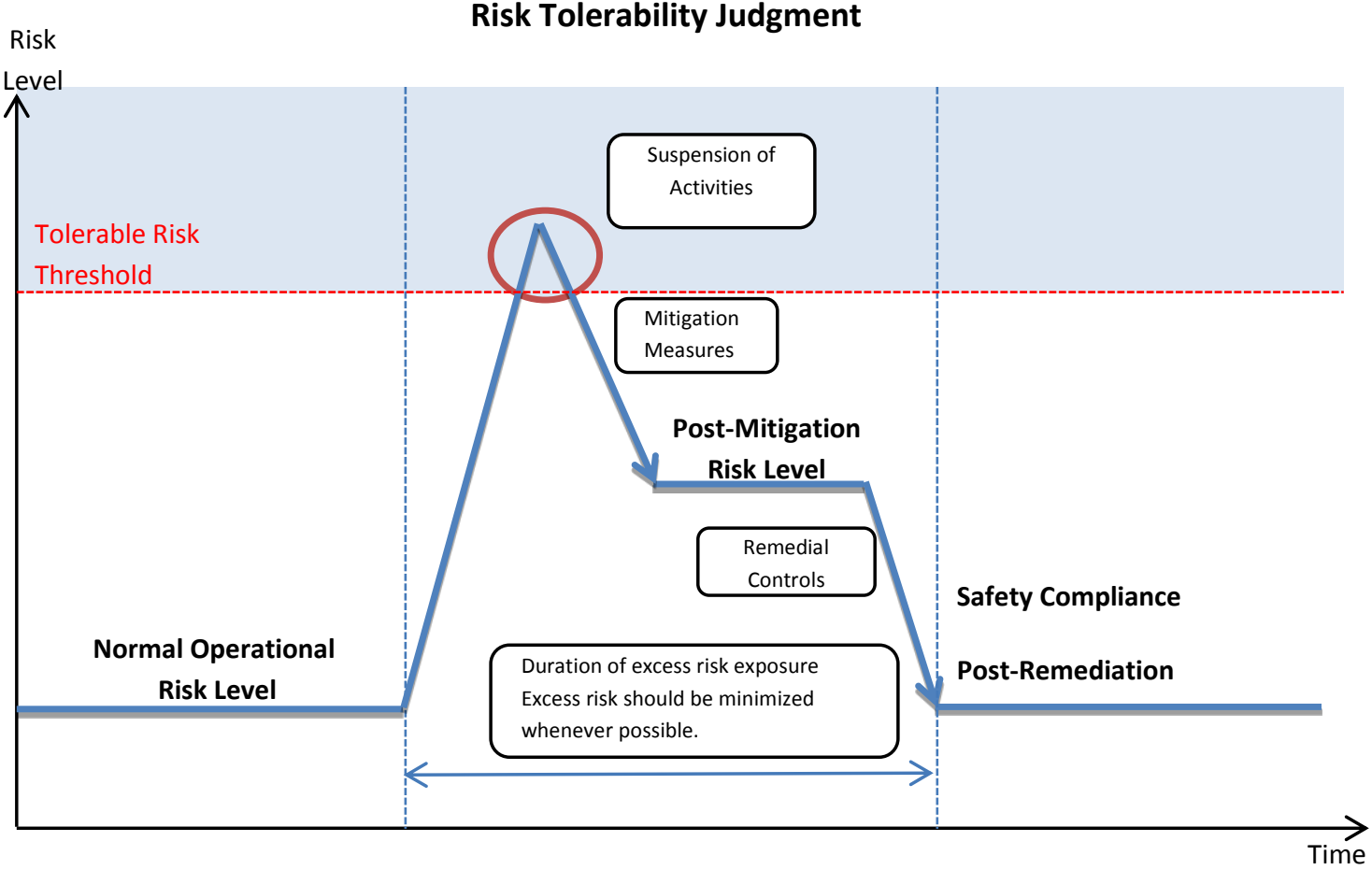

Source: Oil \& Gas UK (2012) 
The model also addresses safety infringements considering the need to use different instruments and involve different actors given the rapid growth of the oil and gas sector. In this sense, it was created a "Multilayer System of Supervision," as shown in Figure $\mathrm{N}^{\circ}$ 9. This system involves, in the construction stages of oil and gas projects, a series of internationally certified companies (contractors) that build the infrastructure, which serves as a first agent that contributes to the reduction of safety risk at the construction stage. These companies are supervised in a first stage by the oil and gas companies themselves. Then, the system requires that accredited certifiers verify the operations of the companies once their infrastructure is put online. These certifiers are accredited by INDECOPI, which is the Peruvian authority in charge of enacting technical norms and performing safety accreditation at a national level. ${ }^{12}$ Finally, OSINERGMIN performs safety inspections based on its risk monitoring model discussed above. OSINERGMIN also requires that companies have insurance policies to compensate affected parties for liabilities generated by accidents or other unforeseen events associated to oil and gas operations. Figure $\mathrm{N}^{\circ} 10$ summarizes the main components of the model described above.

Figure $\mathbf{N}^{\circ} 9$

Multilayer Model of Supervision of Oil and Gas Activities in Peru

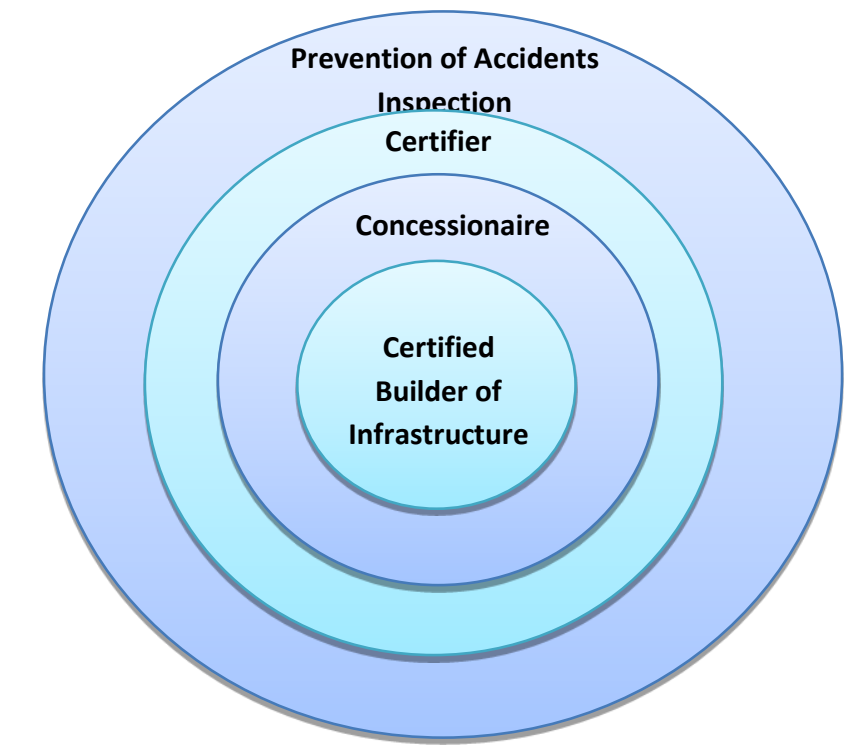

Source: Own elaboration

\footnotetext{
12 INDECOPI hosts the National Accreditation Service, which is the national accreditation agency and as such, it is responsible for the acknowledgement of technical competence of conformity evaluating agencies in all sectors, according to international rules and guidelines, World Trade Organization regulations, free trade agreements and the corresponding supranational and national regulations.
} 
Figure $\mathrm{N}^{\circ} 10$

Integral Model of Safety Regulation in Peru

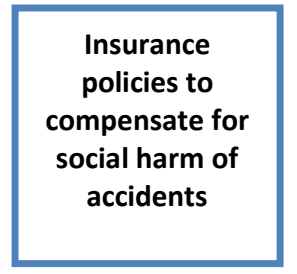

Transparency system in the issuance of certificates (Trust)

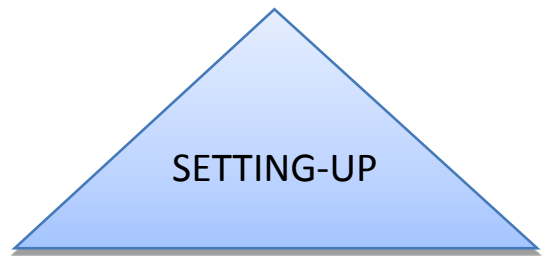

Safety certification of oil and gas facilities
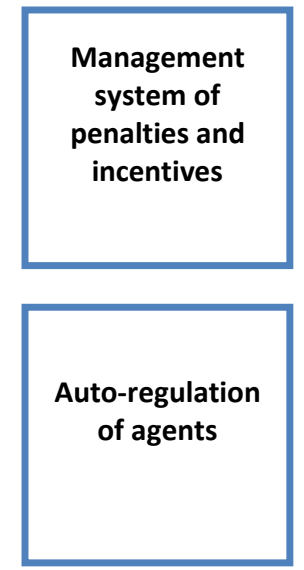

Source: Own elaboration

The model presented in this section has allowed the Peruvian safety regulator to face the challenge of carrying out safety monitoring in a flourishing and growing oil and gas industry in Peru, considering the most important recommendations from economic theory and practice. This model is being applied to almost all stages of the oil and gas upstream sector including large facilities such the LNG export plant located in Pampa Melchorita beach. It focuses on ex ante monitoring so as to prevent the occurrence of catastrophic accident that may arise in from insecure oil and gas activities.

\section{Conclusions}

Failures in safety regulation in the oil and gas industry can generate catastrophic accidents with adverse social consequences of systemic scope. The problem is that the risky technology employed to produce hydrocarbons is progressing at a fast pace each year, but safety regulations to prevent accidents are usually behind the technological developments in the oil and gas sector. This means that safety conditions in an evolving and dynamic industry such as the oil and gas sector could not be monitored appropriately. This problem has not been widely studied in the academic literature; however, recent events, such as the accident of the Deepwater Horizon oil rig in 2010, show that there are some deficiencies in safety regulation in several jurisdictions that are increasing the systemic risk of accidents.

Safety regulation has been delegated by the State to specialized regulatory agencies which are empowered to carry out monitoring and enforcement of safety standards. The problem is that, 
in general, regulatory agencies face limitations to access information regarding the safety effort of oil and gas companies (the moral hazard problem), so there is asymmetric information regarding safety compliance between the regulatory agencies and the companies. This problem has been analyzed in this paper using a principal-agent model in which a regulatory agency (the principal) has to monitor the safety effort of a company (the agent) in order to reduce the informational asymmetry regarding the company's safety behavior and, at the same time, induce it to comply with the safety standards mandated by law.

The policy prescription obtained from the model is that safety compliance is achieved when regulatory agencies monitor companies' safety behavior ex ante and ex post the occurrence of an accident and enforce safety standards in case infringements are detected by applying penalties. In particular, ex ante monitoring has the largest impact in the regulatory framework because it can generate incentives for safety compliance in a preventive way. Failures in the monitoring system, especially in the ex ante stage, can distort the enforcement of safety standards, create excessive levels of risks and increase the probability of accidents. Although autoregulation measures implemented by companies can reduce to some extent the risk of accidents, they do not necessarily guarantee the achievement of the required level of safety compliance mandated by law and must be complemented by State's direct regulations.

Based on this analysis, in Peru OSINERGMIN, the safety regulatory agency of the oil and gas industry in Peru, has been administering a multi-layer supervision model that incorporates the different participants of the industry such as oil and gas companies, other public institutions that regulates the industry, accredited contractors in charge of installing facilities and infrastructure, certifying firms that verify the compliance of safety standards during operations, and its own supervisory team. The model discussed in this paper aims to minimize safety risks associated to the development of the oil and gas infrastructure and its operation by providing a clear assignment of responsibilities to the parties involved in the compliance of safety regulations and the application of economic incentives (penalties) to potential infringers. This model was developed because of the need to adapt safety regulations to a growing oil and gas industry after the start of the Camisea gas project in 2004. Under this new model, OSINERGMIN emphasizes the execution of ex ante monitoring and the prevention of safety risks in order to reduce the frequency and the severity of accidents and its potential consequences on the environment and human health. 
Understanding how to properly regulate the occurrence of oil and gas accidents is fundamental for the legitimacy of the oil industry and governments' stability in a context where citizens demand improvements in safety standards and environmental quality. The theoretical analysis and the study of the Peruvian experience performed in this paper can help oil and gas firms and regulators in different jurisdictions assess the risks involved in oil operations and devise optimal ways to diminish them by considering appropriate regulations that balance the interests of companies and the governments' objective of protecting the environment and human health.

\section{References}

Baumol, W. J., and Oates, W. E. (1988). The theory of environmental policy. Cambridge: Cambridge University Press.

Becker, G. (1968). "Crime and Punishment: An Economic Approach," Journal of Political Economy, 76 (2): 169-217.

Cohen, M. (1987). "Optimal Enforcement strategy to prevent oil spills: An application of a principal-agent model with moral hazard." Journal of Law and Economics," 30(1): 23-51.

Cavnar, R. (2010). Disaster on the Horizon. White River Junction: Chelsea Green.

Hiriart, Y., Martimort, D., and Pouyet, J. (2010). "The public management of risk: Separating ex ante and ex post monitors." Journal of Public Economics, 94(11): 1008-1019.

Hölmstrom, B. (1979). "Moral hazard and observability." The Bell Journal of Economics, 10 (1): 74-91.

Kaplow, L. and S. Shavell (1994). "Optimal Law Enforcement with Self-Reporting of Behavior." Journal of Political Economy, 102 (3): 583-606.

Kolstad, C. D., Ulen, T. S., and Johnson, G. V. (1990). "Ex post liability for harm vs. ex ante safety regulation: substitutes or complements?" The American Economic Review, 80(4): 888-901.

Laffont, J. and D. Martimort (2002). The Theory of Incentives. The Principal-Agent Model. Princeton NJ: Princeton University Press.

Lott, J. R. Jr. (1996). "The Level of Optimal Fines to Prevent Fraud when Reputations exist and Penalty Clauses are Unenforceable", Managerial and Decision Economics, Special Issue: Corporate Crime, 17 (4): 363-380. 
Mondello, G. (2011). “¿Hazardous Activities and Civil Strict Liability: The Regulator’s Dilemma.” Sustainable Development Series. University of Nice Sophia Antipolis.

Oil \& Gas UK (2012). Guidance on the Conduct and Management of Operational Risk Assessment for UKCS Offshore Oil and Gas Operations.

Polinsky, M. and S. Shavell (2000). "The economic theory of public enforcement of law." Journal of Economic Literature, 38(1): 45-76.

Polinsky, M. and S. Shavell (2007). "The theory of public enforcement of law." In Handbook of Law and Economics. Vol. 1: 403-454.

Salvador, J. and Fernández, V. (2011). Supervision Model based on Risk Assessmen for Perut. Presentation at OSINERGMIN.

Shavell, S. (1987). Economic Analysis of Accident Law. Cambridge MA: Harvard University Press.

Shavell, S. (2004). Foundations of economic analysis of law. Cambridge MA: Harvard University Press.

Stavins, R. (1998). "What can we learn from the grand policy experiment? Lessons from SO2 allowance trading." Journal of Economic Perspectives, 12(3): $69-88$.

Tirole, J. (1986). "Hierarchies and bureaucracies: On the role of collusion in organizations." Journal of Law, Economics and Organization, 2(2): $181-214$.

Vásquez, A. (2006a). System of Environmental Penalties for the Supervision of the Oil Industry in Peru. Working Paper No 20, Office of Economic Research, OSINERGMIN.

Available at http://www.osinergmin.gob.pe/newweb/uploads/Estudios_Economicos/DT20_OSINERG.pdf

Vásquez, A. (2006b). The Value of Statistical and its Applications to the Supervision of the Oil Industry. Working Paper No 18, Office of Economic Research, OSINERGMIN.

Available at http://www.osinerg.gob.pe/newweb/uploads/Estudios_Economicos/DT18_OSINERG.pdf

Vásquez, A. (2011). "Introducción a la supervisión y regulación de la seguridad de empresas energéticas." IX Curso de Regulación Energética de ARIAE.

Vásquez, A. (2012). The Regulation of Oil Spills and Mineral Pollution: Policy lessons for the U.S.A. and Peru from the Deep Water Horizon blowout and other accidents. Berlín: Lambert Academic Publishing. Abstract available at 
http://www.osinerg.gob.pe/newweb/uploads/Estudios_Economicos/The\%200ptimal\%20regula tion\%20of\%20accidental\%20pollution\%20and\%20market\%20power\%20in\%20the\%20mineral\% 20and\%20energy\%20industries.\%20aVásquez.pdf

Vásquez, A. y J. Gallardo. (2006). Systems of Supervision and Penalties for the Oil Industry. Working Paper No 10, Office of Economic Research, OSINERGMIN.

Available at

http://www.osinergmin.gob.pe/newweb/uploads/Estudios_Economicos/DT_010_Supervision_y _sanciones.pdf

Villar, J. (2009). Eliminación del mayor impacto ambiental de los campos petroleros. Working Paper. Gerencia de Fiscalización de Hidrocarburos Líquidos, OSINERGMIN.

Villar, J. (2012). La exploración y explotación petrolera en el Perú: Producción y Regulaciones. Gerencia de Fiscalización de Hidrocarburos Líquidos, OSINERGMIN.

Viscusi, W. (1996). Fatal Tradeoffs. Oxford: Oxford University Press

Viscusi, W. K., Vernon, J. y J. Harrington (2000). Economics of Regulation and Antitrust, 3rd Edition. Cambridge MA: MIT Press.

Viscusi, W. (2006). Regulation of health, safety, and environmental risks. Working Paper No 11934. National Bureau of Economic Research.

White House (2011). The Macondo well and the blowout. Final Report, National Commission on the BP Deepwater Horizon Oil Spill and Offshore Drilling. 


\section{Appendix $\mathbf{N}^{\circ}$ 1: System of Self-Reporting through Affidavits}

In Peru, OSINERGMIN has begun to implement changes in its monitoring procedures so as to make efficient the enforcement of safety standards in the gas industry. The most important change was the introduction of a system in which oil and gas companies self-report its degree of safety compliance. This new system facilitates that companies assess the conditions of their safety procedures and the risks of its operations in a preventive manner. Under the system, gas companies have the mandate to send their self-reports to the regulatory agency before ex ante monitoring happens. These self-reports, which have the status of affidavits, contain information regarding the companies' compliance of different safety mandates. Companies have to fill out a checklist containing every safety requirement that that they have to comply by law. In case companies declare that they did not comply with any safety mandate, the regulator initiates an administrative procedure to determine the degree of the fault and may also assess a penalty. If the regulator determines that the fault generates a high risk of an accident, it may also mandate the suspension of activities in the companies' facilities that are unsecure. When companies declare that they are complying with all safety mandates, the regulatory agency proceeds to supervise them in order to evaluate the truthfulness of their self-report. If the regulator discovers that the companies' self-reports are false, the regulator can apply a penalty which will be higher than the penalty applied in case the companies declare the truth when filling out the checklist. $^{13}$

In this system, gas companies have the burden of proof regarding their safety compliance by means of the self-report. However, an advantage of the system is that provides companies with a scheme that foster their own autoregulation regarding their safety effort. In addition, the system allows building a General Compliance Index (GCI). Under this mechanism, the regulator grants an initial bonus of points to each company at the beginning of the monitoring campaign. If a company fails to comply with any safety standard, it will lose some of its allotted points. With this information, the regulator can calculate compliance scores based on the information reported by the company or the information collected in a regular supervision. Once the regulator has the information of all companies, it can build the $\mathrm{GCl}$ for each company and rank

\footnotetext{
${ }^{13}$ According to Kaplow and Shavell (1994), the self-reporting system aims to: i) reduce the costs of supervision (the regulator only have to supervise companies that claim to have met the safety standards) and ii) reduce the perception of risk by firms regarding sanctioned system. However, to guarantee optimal deterrence, the system requires that the penalties for not declaring the truth are greater than those applied when we the companies actually declare that they are not complying with safety mandates.
} 
them depending of their $\mathrm{GCl}$ scores. The regulator with the $\mathrm{GCl}$ can focus on monitoring those companies with the highest scores. 
Supervisory Agency of Investment in Energy and Mining of Peru - OSINERGMIN Office of Economic Analysis - OEE

Institutional Authorities

Jesús Tamayo Pacheco, Eng. Chairman of the Board of Directors

Julio Salvador Jácome, Eng. Chief Executive Officer

Office of Economic Analysis

Arturo Vásquez Cordano, Ph.D. Chief Economist and Manager

Sectoral Specialists:

Raúl García Carpio (Natural Gas), Victor Zurita Saldaña (Mining), Humberto Ortiz Ruiz (Electricity), Ricardo de la Cruz Sandoval (Petroleum)

Economic Analysts:

Erix Ruiz Mondaca (Econometrics), Francisco Coello Jaramillo, Steven Cueva Herrera Assistants:

Tatiana Nario Lazo, Melissa Llerena Pratolongo

Administrative Assistant:

Clelia Bandini Malpartida 


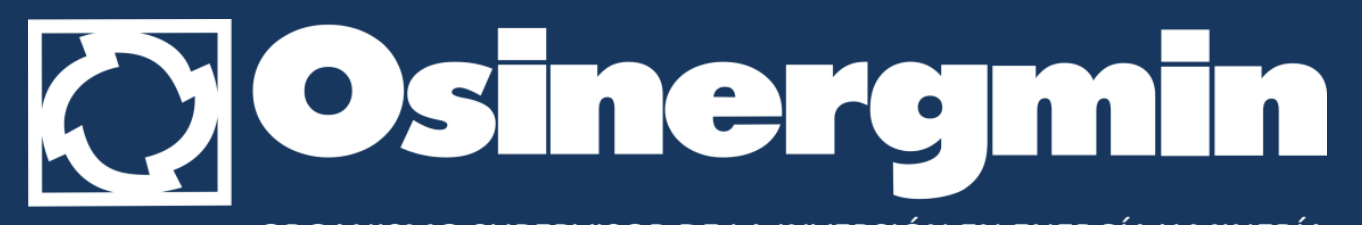

ORGANISMO SUPERVISOR DE LA INVERSIÓN EN ENERGÍA Y MINERÍA

Oficina de Estudios Económicos

Bernardo Monteagudo 222 - Magdalena del Mar - Lima 17

Teléfono: 219-3400 Anexo: 1057 Fax: 219-3413

www.osinergmin.gob.pe

http://www.osinergmin.gob.pe/newweb/pages/Estudios Economicos/77.htm?1288 